\title{
CHALLENGES FACED BY FOREIGN INVESTORS IN THE BRAZIL'S ENERGY SECTOR
}

Fernanda Torres Volpon

$\mathrm{PhDC}$ Candidate in International Law at Rio de Janeiro State University - UERJ. Master of Laws in International Law at Rio de Janeiro State University - UERJ. CAPES Scholarship Student.Student Member of Association of International Petroleum Negotiators (AIPN). Rio de Janeiro State University (UERJ), Brazil.

fernandavolpon@hotmail.com

Luciene Machado

\begin{abstract}
Post-graduated in Corporate Law at Presbiteriana Mackenzie University. Graduated in Law at São Caetano do Sul University - USCS, Brazil. Member of the Brazilian Institute of Energy Law Studies - IBDE.

lucienne.machado@icloud.com
\end{abstract}

Received: 2016-05-17. Accepted: 2016-07-11.

\begin{abstract}
The Brazilian energy sector suffered constantly changes during the past years. The process of transformation looked for a competitive market aiming funds to develop infrastructure in Brazil. Foreign investment is necessary to develop and strengthen the energy market, but the sector still present some challenges to be faced by the foreign investors. As consequence, some questions shall be raised in connection with the real effectiveness of mechanisms imposed to foreign investment at its entrance in the Brazilian energy sector. Does the Brazilian legal framework provide legal certainty to the foreign investors interested in investing in the energy sector? The objective of this article is to provide an overview of reform made to the energy market and current hindrances to the investor's entry in such sector.
\end{abstract}

Keywords: Energy Law - Foreign Investment - Regulatory Panorama

\section{INTRODUCTION}

The energy sector is strategic to the economy of any country 
involving activities regulating an individual daily's life ${ }^{1}$. The energy is a process of transformation that involves technology and economic deployment due to its potential scarcity and possibility of economic exploration. ${ }^{2}$ Considering the major relevance taken in a country's economy, the energy system requires a high volume of (national and foreign) investment. In line with such need, an adequate regulation and lawmaking process turns to be essential for the investment attraction in the energy field. As the Brazilian energy sector is an ongoing developing environment, the legislative and regulatory framework shall provide a response to the needs of public and private actors operating in such market.

Unfortunately, there are some public policies that are not favorable for the investor who intends to acting in the Brazilian energy sector: they do not promote and create attractiveness to the private actors to invest money and risk their reputation in certain projects. This paper examines the rules governing the Brazilian energy sector specially focused on the mechanisms of foreign investors' access to such market. The main objective is to examine the instruments that help along with the obstacles that hinder (intentionally or unintentionally) the access of foreign investors to the Brazilian energy market.

In order to pursue the objective of this paper, the authors will firstly present an historical approach of the regulatory changes experienced in the energy sector together with its political and economic factors that influenced such transformations. At a second moment, an analysis will be made over the national legislation and regulatory requirements applicable to the energy sectors that foreign investors shall be mindful to it. At last, the authors will examine the challenges faced by the foreign investors to access Brazilian's energy sector that should be improved. The methodology used in this work is the analysis of national legislation, regulatory rules and concession bid documents imposed by the Brazilian State and regulatory agencies for private investors.

\section{A BRIEF HISTORICAL APPROACH OF THE LEGISLATIVE TRANSFORMATIONS OCCURRED IN THE BRAZILIAN ENERGY SECTOR}

In the early of the 20th century the electricity industry in Brazil was composed, for the most part, by private companies as Light and American \& Foreign Power Co. (Amforp), whose origin were Canadian and American, respectively. ${ }^{3}$ Due to the lack of specific legislation in

1 LEAL-ARCAS, Rafael; FILIES, Andrew; ABU GOSH, Ehab S. International Energy Governance: Selected Legal Issues. Cheltenham: Edward Elegar, 2014, p. 15.

2 ROLIM, MARIA J. Direito Econômico da Energia Elétrica. Rio de Janeiro: Forense, 1a ed., 2002, p. 98.

3 TOLMASQUIM. Maurício T. Novo Modelo do Setor Elétrico Brasileiro. Rio de Janeiro: 
this field, the electricity services were regulated by contracts between entrepreneurs ${ }^{4}$ and the municipal governments and those contracts had as main object the occupation of public assets and hydro-generation potential by entrepreneurs.

The 1934 Brazilian Federal Constitution defined a new scenario for the Brazilian energy sector. The Constitution of 1934 ensured to the Brazilian Government the centralization of exploitation of hydrogeneration energy within the national territory. ${ }^{5}$ In the same year, the Decree-Law No. 24.643/1934 ("Code of Waters") was enacted, limiting the term for concessions regarding energy in thirty years. However, if there were significant investments by entrepreneurs, the concessions' regular term could be extended reaching fifty years. ${ }^{6}$

In order to verify the activities exercised by the private companies, which obtained the authorization or concession for construction of hydroelectric plants and thermal power plants, the Code of Waters established the right of the public authorities to supervise the companies in the electrical industry ${ }^{7}$. The Code of Waters also

Synergia, 2a ed., 2011, p. 3.

4 According Luiz Gustavo Loureiro Kaercher, entrepreneurs can be defined as companies that occupied public properties. In the case of energy, the entrepreneurs occupied rivers, which are part of the Brazilian's government ownership. These companies exploited the river's electric potential to generate energy that was sold by Municipal governments through contracts. KAERCHER Loureiro, Luiz Gustavo. A Indústria Elétrica e o Código de Águas. Porto Alegre: Fabris, 2007, p. 27.

5 Article 119 of Brazilian Federal Constitution of 1934 provides "The industrial use of mines and mineral deposits, as well as water and hydroelectric power, although privately owned, depends on the authorization or concession of the Federal Governments in the form required by law". ("O aproveitamento industrial das minas e das jazidas minerais, bem como das águas e da energia hidráulica, ainda que de propriedade privada, depende de autorização ou concessão federal, na forma da lei”). BRASIL. Constituição da República Federativa dos Estados Unidos do Brasil de 16 de Julho de 1934. Available at: http:/www.planalto.gov.br/ccivil_03/ Constituicao/Constituicao34.htm. Access on June 24, 2016.

6 Article 157 of Decree-Law No. 24.642/1934 provides that concessions related to production, transmission or distribution of hydro energy shall have a regular term of 30 years and an exceptional term of 50 years if the works and installations requires more investment. ("As concessões, para producção, transmissão e distribuição da energia hydro-electrica, para quaesquer fins, serão dadas pelo prazo normal de 30 annos. Paragrapho unico. Excepcionalmente, si as obras e installações, pelo seu vulto, não comportarem amortização do capital no prazo estipulado neste artigo, com o fornecimento de energia por preço razoável, ao consumidor, a juízo do Governo, ouvidos os orgãos technicos e administrativos competentes, a concessão poderá ser outorgada por prazo superior, não excedente, porém, em hypothese alguma, de 50 annos."). BRASIL. Câmara dos Deputados. Decreto no 24.643 de 10 de julho 1934. Available at: http://www2.camara.leg.br/legin/fed/decret/1930-1939/decreto-24643-10-julho-1934498122-publicacaooriginal-1-pe.html. Access on June 21, 2016.

7 Article 144 of Decree-Law No. 24.642/1934 provides that the Agriculture Ministry is the competent body of Federal Government to supervise production, transmission and distribution 
established the criteria to require simplified process of authorization or concession to explore the hydro-generation energy ${ }^{8}$ and other relevant provisions related to the exploration of hydro-generation activities.

Later, the Decree-Law No. 852/1938 brought new requirements to the concessions in the energy field, specifically in relation to the construction of transmission lines and distribution networks. This legislation substantially modified the Code of Waters, representing a reconstruction of the Brazilian energy sector, which was not truly regulated until then. The article 5 of Decree-Law No. 852/1938 established the need for authorization or concession for "the establishment of transmission lines or distribution networks for energy". ${ }^{9}$ In 1940, the requirement of authorization or concession for construction of hydroelectric plants and thermal power plants came into force. ${ }^{10}$ Following the trend of the Code of Waters, the DecreeLaw No. 3.763/1941 established the supervision to be performed by the public authorities, including the supervision over the accounting field in order to guarantee the services provided to the population were appropriate, the power tariffs were reasonable and the companies presented a financial stability. ${ }^{11}$

of hydroelectric energy. ("O Serviço de Águas do Departamento Nacional de Produção Mineral do Ministério da Agricultura, é o órgão competente do Governo Federal para: c) fiscalizar a produção, a transmissão, a transformação e a distribuição de energia hidro-elétrica; BRASIL. Câmara dos Deputados. Decreto no 24.643 de 10 de julho 1934 (Redação dada pelo Decretolei $\mathrm{n}^{\mathrm{o}} 3.763$, de 25.10.1941) Available at: http://www.planalto.gov.br/ccivil_03/decreto/d24643. htm. Access on June 23, 2016.

8 Article 140 of Decree-Law No. 24.642/1934 provides that the concession is required for the utilization of: (i) the waterfall and other sources of hydro power output exceeding $150 \mathrm{KW}$ or; (ii) the power plants that are intended for services of Federal, State or Municipal public utility or those which are intended for the energy trade. ("São considerados de utilidade pública e dependem de concessão. a) os aproveitamentos de quedas d'agua e outras fontes de energia hidráulica de potência superior a 150 kws. Seja qual for a sua aplicação. b) os aproveitamentos que se destinam a serviços de utilidade publica federal, estadual ou municipal ou ao comércio de energia seja qual for a potência"). The article 141 of such Decree-Law establishes the criteria for simple authorization, which are applicable for those plants with a maximum generation of 150KW. BRASIL. Câmara dos Deputados. Decreto no 24.643 de 10 de julho 1934. Available at: http://www.planalto.gov.br/ccivil_03/decreto/d24643.htm. Access on June 23, 2016.

9 BRASIL. Câmara dos Deputados. Decreto no 24.643 de 10 de julho 1934. Available at: http:// www.planalto.gov.br/ccivil_03/decreto-lei/1937-1946/Del0852.htm. Access on July 03, 2016. 10 GANIM, Antonio. Setor elétrico brasileiro: aspectos regulamentares, tributários e contábeis. Rio de Janeiro: Canal Energia: Synergia, 2009. p. 41.

11 Article 178 In the performance of the tasks conferred, the division of the National Department of Mineral Production shall supervise the production, transmission, transformation and distribution of energy hydro-electric, with the threefold purpose of: a) ensure adequate service; b) establish reasonable tariffs; c) to ensure the financial stability of companies. For such purposes, shall exercise the supervision of companies' accounts. ("No desempenho das atribuições que lhe são conferidas, a Divisão de Aguas do Departamento Nacional da Produção 
The 1940's era was marked by the Federal Government's concentrated power and its intervention in the economy. Due to the high demand resulting from industrialization and such 'intervener role', the Brazilian Government has also adopted the role of entrepreneur in the energy sector. The Decree-Law No. 8.031/1945 has represented this intervention period as it provided the authorization for the creation and subsequent construction of hydro-electric Company from São Francisco named in Portuguese 'Chesf'. ${ }^{12}$ This was the first public company of electric sector and its creation constituted a public action in accordance with the concessions' framework established in the Code of Water which provided: "The creation of Chesf represented a new stage in the development of the Brazilian electricity sector, marking the trend of decoupling between generation transmission and distribution of electric energy and also concentrating production in large power plants"13.

The concentration of Government's power in the energy sector was consolidated in 1962, when 'Eletrobrás' (a Brazilian public company) was created. ${ }^{14}$ This public company focused its activities in planning, coordinating, supervising construction programs, in the expansion and operation of generation's systems, transmission and distribution of electricity ${ }^{15}$ resulting in the expansion of energy sector. This model has brought positive effects to the energy market with a

Mineral fiscalizará a produção, a transmissão, a transformação e a distribuição de energia hidroelétrica, com o tríplice objetivo de: a) assegurar serviço adequado; b) fixar tarifas razoaveis; c) garantir a estabilidade financeira das empresas. Parágrafo único. Para a realização de tais fins, exercerá a fiscalização da contabilidade das empresas"). BRASIL. Decreto-Lei no 3.763/1941 Consolida disposições sobre águas e energia elétrica, e dá outras providências. Available at: http://www.planalto.gov.br/ccivil_03/Decreto-Lei/1937-1946/Del3763.htm\#art144c. Access on June 23, 2016.

12 The Decree-Law 8.031/1945 provides in the Article 1 the creation of "Hydro-electric Company" from São Francisco named in Portuguese 'Chesf'. ("Fica o Ministério da Agricultura autorizado a organizar uma sociedade por ações, com sede e foro na cidade do Rio de Janeiro, destinada a realizar o aproveitamento industrial progressivo da energia hidráulica do Rio São Francisco. Parágrafo único. Na organização da Sociedade, que se denominará Companhia Hidro Elétrica do São Francisco, observar-se-ão as normas constantes dos Estatutos anexos ao presente decreto-lei”). BRASIL Decreto-Lei no 8.031 de 03 de outubro de 1945. Autoriza a organização da Companhia Hidro Elétrica do São Francisco. Available at: http://www.planalto. gov.br/ccivil_03/decreto-lei/Del8031.htm. Access on June 23, 2016.

13 CALDAS, Geraldo P.. Concessões de serviços públicos de energia elétrica. Curitiba: Juruá. 2a ed., 2011. p. 44.

14 Eletrobrás was created by the Decree-Law no 3.890-A/1961. BRASIL. Decreto Lei $N^{\circ}$ 3.890-A/1961. Autoriza a União a constituir a empresa Centrais Elétricas Brasileiras S. A. ELETROBRÁS, e dá outras providências. Available at: http://www.planalto.gov.br/ccivil_03/ leis/L3890Acons.htm Access on June 24, 2016

15 CALDAS, Geraldo P.. Concessões de serviços públicos de energia elétrica. Curitiba: Juruá. 2a ed., 2011. p. 44. 
significant increase of electricity supply to the Brazilian population.

During the mid-1980s, a serious crisis smacked the electric sector. This crisis was triggered off by the elimination of some taxes, which resulted in the termination of funding for the energy sector. The phenomenon of funds shortage in the energy sector occasioned the inability of the public sector to invest and promote the necessary growth in the energy sector ${ }^{16}$ causing several negative effects to such sector.

Until the early $1990 \mathrm{~s}$, the model of state monopoly was still in force in the energy sector. Nevertheless the presence of the public influence in the sector, the events occurred in the 1980s and the financial crisis faced in several areas of the economy evidenced the intervention model present was weak and inefficient.

In order to achieve improvements in the economy as a whole, a regime based on the competition was introduced. Such regime needed to be implemented through a privatization process of public companies, which reduced their market power and established a competition regime among other companies present in the field of energy. ${ }^{17}$

After the 1980s crisis, the Brazilian Federal Government decided to pursue a reform in the energy sector. In the beginning of the 1990's, the Federal Government gave an incentive to the States to privatize public companies, especially the power distributors, aiming to obtain financial resources and establish a competitive system in the energy sector. ${ }^{18}$

In 1995, the Law No. 8.987/1995 (Concessions Law) was enacted. The Concessions Law established general rules as a guidance for the concessions, permission as authorizations to be established in the energy sector, as well as the rights and obligations of the concessionaires of public service and users. The Concessions Law also established rules for tariff adjustments and mechanisms of reassessments of public concessions, which were required for the maintenance of the economic and financial equilibrium of concessions. ${ }^{19}$

In the same year, Law No. 9.074/1995 (Energy Concessions Law) brought important changes to the energy sector because it has

16 TOLMASQUIM. Maurício T. Novo Modelo do Setor Elétrico Brasileiro. Rio de Janeiro: Synergia, 2a ed., 2011, p. 5.

17 TOLMASQUIM. Maurício T. Novo Modelo do Setor Elétrico Brasileiro. Rio de Janeiro: Synergia, 2a ed., 2011, p. 6.

18 Light, CPFL, Cerj, Enersul, Cemat, Coelba, Celce and others are examples of power distributors companies that were privatized in the beginning of the 1990's. Available at: http://www.bndes.gov.br/SiteBNDES/export/sites/default/bndes_pt/Galerias/Arquivos/ conhecimento/pnd/Priv_Gov.PDF. Access on June 24, 2016.

19 BRASIL. Lei No 8.987, de 13 de fevereiro de 1995. Dispõe sobre o regime de concessão e permissão da prestação de serviços públicos previsto no art. 175 da Constituição Federal, e dá outras providência. Available at: http://www.planalto.gov.br/ccivil_03/leis/L8987cons.htm Access on June 21, 2016. 
created important figures to continue boosting the competitiveness in the market. ${ }^{20}$ Along with the Energy Concessions Law, the figure of 'Independent Power Producer' has appeared, ${ }^{21}$ and 'Free Consumer'. The main change provided by the Energy Concessions Law was the permission for the Independent Power Producer and Free Consumer to negotiate the price of electricity produced. ${ }^{22}$ As a result of such modification in the legislation, the Free Consumer was not obligated to buy energy from a local distributor power. In addition to that fundamental change, the Law No. 9.074/1995 has also established that the power distributing companies could not carry another economic activity except the power distribution. The main objectives of such measure were the maintenance of the distributors' monopoly ${ }^{23}$ and the

20 BRASIL. Lei $N^{\circ}$ 9.074, de 7 de julho de 1995. Estabelece normas para outorga e prorrogações das concessões e permissões de serviços públicos e dá outras providências. Available at: http:// www.planalto.gov.br/ccivil_03/leis/L9074cons.htm Access on June 21, 2016.

21 Article 11 of Law No. 9.074/95 established the creation of 'Independent Power Producer' figure in the energy sector. The Independent Power Producer is a company that receives concession or authorization from the Federal government to generating energy for the trade of all or part of the energy generated at its own risk. ("Considera-se produtor independente de energia elétrica a pessoa jurídica ou empresas reunidas em consórcio que recebam concessão ou autorização do poder concedente, para produzir energia elétrica destinada ao comércio de toda ou parte da energia produzida, por sua conta e risco. Parágrafo único. O Produtor Independente de energia elétrica estará sujeito às regras de comercialização regulada ou livre, atendido ao disposto nesta Lei, na legislação em vigor e no contrato de concessão ou no ato de autorização, sendo-lhe assegurado o direito de acesso à rede das concessionárias e permissionárias do serviço público de distribuição e das concessionárias do serviço público de transmissão".) BRASIL. Lei No 9.074, de 7 de julho de 1995. Estabelece normas para outorga e prorrogações das concessões e permissões de serviços públicos e dá outras providências. Available at: http:// www.planalto.gov.br/ccivil_03/leis/L9074cons.htm. Access on June 24, 2016.

22 Article 15 of Law No. 9.074/1995 established the figure of 'Free Consumers' classified as consumers of electricity with consumption charge of $10.000 \mathrm{~kW}$ or more, with a voltage of $69 \mathrm{kV}$ or higher. These consumers are free to buy energy from Independent Power Producers. ("Respeitados os contratos de fornecimento vigentes, a prorrogação das atuais e as novas concessões serão feitas sem exclusividade de fornecimento de energia elétrica a consumidores com carga igual ou maior que $10.000 \mathrm{~kW}$, atendidos em tensão igual ou superior a $69 \mathrm{kV}$, que podem optar por contratar seu fornecimento, no todo ou em parte, com produtor independente de energia elétrica"). BRASIL. Lei № 9.074, de 7 de julho de 1995. Estabelece normas para outorga e prorrogações das concessões e permissões de serviços públicos e dá outras providências. Available at: http://www.planalto.gov.br/ccivil_03/leis/L9074cons.htm. Access on June 24, 2016.

23 Article 4, Paragraph 5 of the Law No. 9.074/1995 provides the monopoly of the energy distributors. The distributors are not allowed to sell energy in the market as generator, transmitters or traders. BRASIL. Lei $n^{\circ}$ 9.074/1995 Estabelece normas para outorga e prorrogações das concessões e permissões de serviços públicos e dá outras providências. ("Art. 4o As concessões, permissões e autorizações de exploração de serviços e instalações de energia elétrica e de aproveitamento energético dos cursos de água serão contratadas, prorrogadas ou 
encouragement of the free initiative of segments such as generation and trade of energy.

It is important to note that the segregation of generation, transmission and distribution ${ }^{24}$ sectors was a necessary step for the Brazilian energy market. ${ }^{25}$ The segregation was necessary to create a more competitive segment of energy's generation, especially by the introduction of energy traders. ${ }^{26}$ On the one hand, the introduction of energy trader in the market has improved the competitiveness in the energy sector. On the other hand, it has maintained energy tariff regulation in the transmission and distribution field due to the fact that the companies exercising activities in this sector had a background in the original public monopoly. ${ }^{27}$

Nonetheless the modifications made to the energy sector in the 1990's, the inefficiency was still present in the sector. In 2001, the public authorities verified that the water reservoirs (the largest source of power generation in

outorgadas nos termos desta e da Lei no 8.987, e das demais. (...) $\S 5^{\circ}$ As concessionárias, as permissionárias e as autorizadas de serviço público de distribuição de energia elétrica que atuem no Sistema Interligado Nacional - SIN não poderão desenvolver atividades: (Incluído pela Lei $\mathrm{n}^{\circ} 10.848$, de 2004) I - de geração de energia elétrica; II - de transmissão de energia elétrica; III - de venda de energia a consumidores de que tratam os arts. 15 e 16 desta Lei, exceto às unidades consumidoras localizadas na área de concessão ou permissão da empresa distribuidora, sob as mesmas condições reguladas aplicáveis aos demais consumidores não abrangidos por aqueles artigos, inclusive tarifas e prazos; IV - de participação em outras sociedades de forma direta ou indireta, ressalvado o disposto no art. 31, inciso VIII, da Lei no 8.987, de 13 de fevereiro de 1995, e nos respectivos contratos de concessão; ou V - estranhas ao objeto da concessão, permissão ou autorização, exceto nos casos previstos em lei e nos respectivos contratos de concessão"). Available at: http://www.planalto.gov.br/ccivil_03/leis/L9074cons.htm. Access on July 1, 2016.

24 The generation process comprehends the transformation of primary energy to electricity. The transmission segmentation consists of the transportation of energy from the generation plant to the distribution system. The distributor transmits the electricity to the final consumers. ROLIM, MARIA J. Direito Econômico da Energia Elétrica. Rio de Janeiro: Forense, 1a ed., 2002, p. 106-107.

25 Unbundling in the electricity sector involved all regulated companies that were vertically integrated. The result was the separation between generation, transmission and distribution activities in the energy sector. GALLO, Fabiano; LOBIANCO, Eduardo L. Electricity regulation in Brazil: overview. Available at: http://us.practicallaw.com/8-545-7207?q=campos + mello. Access on June 30, 2016, p. 3.

26 The energy traders are allowed to negotiate the energy's price with generators. ("O comercializador de energia elétrica possui competência para negociar livremente o preço da energia elétrica com os geradores"). BRASIL. Lei N ${ }^{\circ} 10.848$ de 15 de março de 2004. Dispõe sobre a comercialização de energia elétrica. Available at: http://www.planalto.gov.br/ ccivil_03/_ato2004-2006/2004/lei/110.848.htm. Access on June 23, 2016.

27 TOLMASQUIM. Maurício T. Novo Modelo do Setor Elétrico Brasileiro. Rio de Janeiro: Synergia, 2a ed., 2011, p. 7. 
Brazil) were below $40 \%$ of the level of storage capacity. ${ }^{28}$ Facing a high demand and low source of energy, an electricity-rationing program in Brazil was an inevitable measure to be taken by the public authorities.

In June 2001, the Federal Government determined a program of electricity rationing throughout the national territory, except for the Southern Region. ${ }^{29}$ In this scenario, the Federal Government took several measures such as: (i) establishment of consumption quotas for the private consumers (residences and industries were authorized to consume a specific amount of energy per month), (ii) increase of tariffs imposed on the electrical energy and (iii) payment of bonuses for users who have saved energy during the rationing's period. ${ }^{30}$ In February 2002, almost one year later, the Operator of the National Electricity System (ONS) ${ }^{31}$ determined that the electricity-rationing program should be terminated. ${ }^{32}$

The Brazilian energy crisis in 2001 evidenced the institutions in place and the regulation over the energy sector needed a structural change. The public and private actors observed that the legislation and regulation over the energy sector was clearly vague and sometimes contradictory. The crisis laid off private investors ${ }^{33}$ of the energy sector and a new system with bodies capable of guiding and supervising the energy activities was created.

This movement was essential for the restructure, development and operation of the energy sector. In order to address the need for change,

28 TOLMASQUIM. Maurício T. Novo Modelo do Setor Elétrico Brasileiro. Rio de Janeiro: Synergia, 2a ed., 2011, p. 14.

29 The program of electricity rationing in Brazil in 2001. Available at http:/www.planalto.gov. br/ccivil_03/resolu\%C3\%A7\%C3\%A3o/RES04-01.htm Access on July 08, 2016.

30 TOLMASQUIM. Maurício T. Novo Modelo do Setor Elétrico Brasileiro. Rio de Janeiro: Synergia, 2a ed., 2011, p. 16.

31 Operator of the National Electricity System (ONS). "The basic role of the ONS is to coordinate and monitor generation and transmission operations in the national interconnected system (Sistema Interligado Nacional (SIN)), subject to regulation and supervision by ANEEL. Its institutional mission is to ensure users of the SIN of the continuity, quality and cost-efficient supply of electric energy. It also proposes expansions of the network and reinforcement of existing systems to be considered in planning extensions of transmission systems as well as rules for operating transmission installations in the SIN grid, subject to approval by ANEEL". GALLO, Fabiano; LOBIANCO, Eduardo L. Electricity regulation in Brazil: overview. Available at: http://us.practicallaw.com/8-545-7207?q=campos+mello. Access on June 30, 2016, p.2.

32 Operator of the National Electricity System. Available at: http://www.ons.org.br/sala imprensa/informativos_comunicado_racionamento.htm. Access on June 24, 2016.

33 The private actors were no longer negotiating with companies of the energy sector due to the lack of legal certainty, reason why they were laid off of the energy market. TOLMASQUIM. Maurício T. Novo Modelo do Setor Elétrico Brasileiro. Rio de Janeiro: Synergia, 2a ed., 2011, p. 19. 
the Federal Government created the Ministry of Mines and Energy ${ }^{34}$ (in Portuguese, Ministério de Minas e Energia - MME), responsible for the creation and implementation of policies in the energy sector. It also created the Brazilian Electricity Regulatory Agency ${ }^{35}$ (in portuguese, Agência Nacional de Energia Elétrica - ANEEL) responsible for the regulation and supervision of the activities developed by agents of generation, transmission, distribution and traders of energy sector.

Currently, the negotiations for trading energy in the Brazilian energy market are held in two different markets. They are called 'Regulated Market' (in Portuguese, Ambiente de Contratação Regulada) and the 'Free Market' (in portuguese, Ambiente de Contratação Livre).

In the Free Market, generators, independent power producer, traders and free consumers are free to negotiate agreements of energy by establishing volumes, prices and terms of supply at their own discretion. These transactions are agreed through energy purchase agreement held in the Free Market. In the Regulated Market, the purchase of electricity may only occur upon public auctions formally established by the 'Chamber of Commerce of Electric Energy' (in portuguese, Câmara de Comercialização de Energia Elétrica) and by delegation of the Brazilian Electricity Regulatory Agency. In this case, the energy traders who join the public auctions shall formalize their commercial negotiations by means of a public agreement registered within the Regulated Market. ${ }^{36}$

The segregation between the Regulated Market and the Free Market was a direct result from the segmentation of energy sector in terms of generation, transmission, distribution and trading of energy. As earlier mentioned, this process has promoted competition among the energy agents, as well as maintained the distribution and transmission's sectors regulated.

\section{The PANORAMA OF FOREIGN INVESTORS' REQUiREMENTS TO THE ENERGY'S FOREIGN DIRECT INVESTMENT IN BRAZIL}

The main objective of the several reforms implemented in the Brazilian energy sector was to build a competitive market in order to

34 BRASIL. Lei $n^{0}$ 8.422/1992. Dispõe sobre a organização de ministérios e dá outras providências. Available at: http://www.planalto.gov.br/ccivil_03/leis/L8422.htm. Access on June 24, 2016.

35 ANEEL was established in 1996 by Law No. $9.427 / 1996$ with the main purpose of regulating and supervising the generation, distribution, trading and transmission of energy. The preparation and supervision of public bidding process are one of ANEEL's responsibilities according article 3 of Law No. 9.427/1996. Available at: http://www.planalto.gov.br/ccivil_03/leis/L9427cons. htm. Access on June 30, 2016.

36 For information regarding the Chamber of Commerce of Electric Energy. Available at: https://www.ccee.org.br. Access on June 24, 2016. 
attract more investments and resources to finance the energy sector and develop infrastructure. The new regulation model pursued a mechanism of liberalization with less State-intervention, authorizing the generation and distribution of electrical services to be executed by private corporations. Along with such authorization, public companies were privatized, consolidating the new paradigm of private sector as investor of the energy sector.

The latest events in the energy sector's regulatory scenario have proved to be favorable to the foreign investors. In line with the investorpromotion attitude, Brazilian Government has promoted events to announce to foreign investors that old restrictions to their access to the Brazilian energy sector were removed. ${ }^{37}$ The then Minister of Mines and Energy, Eduardo Braga, announced in October 2015 that Brazil government does not impose hindrances to the foreign investor in the energy sector. Eduardo Braga also reaffirmed the legal certainty remain as one of the main commitments from Brazil's public policy and the current tariff systems is very favorable to foreign investors at the present moment. ${ }^{38}$

The objective of this topic is to understand the necessary steps to be followed by the foreign investor at the moment of decision to pursing an investment in the Brazilian energy sector. The options of investment in the energy sector include the energy trading and participation of public auctions for energy generation or transmission of electricity in the Brazilian territory. These investments are materialized through concession agreements with a characteristic of long-term investments, balancing the risk of the investment together with the possibility of more profit. ${ }^{39}$

37 The Brazilian Decree 5.163/2004, article 19, provides that public bidding processes involving contracts related to energy shall observe guidelines established by the Ministry of Mines and Energy. The Ministry of Mines and Energy is the government body responsible for regulating and supervising the energy sector in Brazil. BRASIL. Decreto 5.163/2004. Regulamenta a comercialização de energia elétrica, o processo de outorga de concessões e de autorizações de geração de energia elétrica, e dá outras providências. Available at: http://www.planalto.gov.br/ ccivil_03/_ato2004-2006/2004/decreto/d5163.HTM. Access on June 28, 2016.

38 BRASIL. Ministério de Minas e Energia. Available at: http://www.mme.gov.br/web/guest/ pagina-inicial/manchete/-/asset_publisher/neRB8QmDsbU0/content/setor-eletrico-brasileiroesta-aberto-a-investimentos-estrangeiros-e-sem-restricoes-diz-braga;jsessionid=148F3 A $851 \mathrm{~F}$ C66A0C0AEAA8D601BE0195.srv154. Access on June 28, 2016.

39 Article 4, paragraph 3 of Law No. 9.074/2004 establishes the regular term for concessions in transmission of lines or distribution of energy is 30 years. BRASIL. Lei $\mathrm{N}^{\circ} 9.074$, de 7 de julho de 1995. Estabelece normas para outorga e prorrogações das concessões e permissões de serviços públicos e dá outras providências. Available at: http://www.planalto.gov.br/ccivil_03/ leis/L9074cons.htm. Access on July 06, 2016. The renovation of concession term in respect of energy generation and transmission shall be limited to one renovation of 30 years-term. BRASIL. Lei $N^{\circ} 12.783$, de 11 de janeiro de 2013. Dispõe sobre as concessões de geração, 
Therefore, the requirements hereby to be analyzed are directed to the foreign direct investment (FDI) in the Brazilian energy market instead of the requirements for the entrance of portfolio investment. The FDI is a type of investment characterized by long-term, transfer of a considerable amount of funds, intention of obtaining profit for a long period and management of the project. ${ }^{40}$ There are other elements, which also characterize the FDI, such as some sort of control and management capacity over the corporation, meaning the interference in the business activities. ${ }^{41}$ The investment of portfolio is focused in the financial market with short-term transactions. "Portfolio investment is normally represented by a movement of money for the purpose of buying shares in a company formed or functioning in another company". ${ }^{2}$

This paper is directed to the energy generation and electricity production for commercial purposes ${ }^{43}$ as it can be a very attractive market for foreign investors due to the available opportunities of investment and profit. ${ }^{44}$ Energy generation may involve traditional sources of energy and the non-traditional sources focused on renewable

transmissão e distribuição de energia elétrica, sobre a redução dos encargos setoriais e sobre a modicidade tarifária. Available at: http://www.planalto.gov.br/ccivil_03/_ato2011-2014/2013/ Lei/L12783.htm Access on July 06, 2016.

40 Rudolph Dolzer and Christoph Schreuer make appoints the elements that characterize each type of investment: "Economic science often assumes that a direct investment involves (a) the transfer of funds, (b) a longer term project, (c) the purpose of regular income, (d) the participation of the person transferring the funds, at least to some extent, in the management of the project, and (e) a business risk. These elements distinguish foreign direct investment from a portfolio investment (no element of personal management), from an ordinary transaction for purposes of sale of a good or a service (no management, no continuous flow of income), and from a short-term financial transaction". DOLZER, Rudolph; SCHREUER, Christoph. Principles of International Investment Law. Oxford: Oxford University Press, 2nd ed., 2012, p. 60 .

41 COSTA, José Augusto Fontoura. Direito internacional do investimento estrangeiro. Curitiba: Juruá, 2010, p. 36.

42 SORNARAJAH, M. The International Law on Foreign Investment. 3nd ed., New York: Cambridge University Press, 2010, p. 8.

43 In this sense, the generation of energy focused on private purposes for individual use is not part of the analysis of this paper.

44 There are several ongoing discussions in the international literature in respect of energy governance and the shift of energy production to the renewables. See: "Were we to shift reliance on energy production to the exploitation of renewables (e.g., power derived from the sun, wind, oceans, and from the heat of the earth), which are abundant, more sustainable and distributed more widely, the zero-sum logic that underlines interstate energy relations could become obsolete". LEAL-ARCAS, Rafael; FILIES, Andrew; ABU GOSH, Ehab S. International Energy Governance: Selected Legal Issues. Cheltenham: Edward Elegar, 2014, p. 21. 
energy. ${ }^{45}{ }^{46}$ The promotion of investment in the energy sector may be two-fold: Government's public investment directly in infrastructure or initiating public auctions to private actors.

The article 176 of Brazilian Federal Constitution establishes the Federal Government's monopoly over the use of natural resources allowing its direct exploration or indirect exploration via concessions, permissions or authorizations. ${ }^{47}$ According to the current Brazilian legislation, any concession, permission or authorization to explore services and installations of electrical energy and use of water with energy purposes shall observe the rights and obligations provided by Law No. 8.987/95 (Concessions Law) and Law No. 9.074/2004 (Energy Concessions Law). Such concession, permission or authorization shall be made in favor of the Brazilian Federal Government. ${ }^{48}$

The Energy Concessions Law provides the companies authorized as distributors of energy are not authorized to directly or

45 A distinction between renewable and non-renewable energy may be clarified as following: the renewable is the energy resources easily replaced by the nature (such as wind, sun, biomass, among others) and the non-renewable which its sources are not instantly replace such as oil and gas. PRADO, Thiago G. F. Políticas públicas e programas de desenvolvimento energético com foco em energias renováveis no brasil: do planejamento setorial de infraestrutura em energia às perspectivas de mudanças globais para o acesso e uso de recursos energéticos. 2014. $256 \mathrm{f}$. Tese (Doutorado em Engenharia Elétrica) - Faculdade de Tecnologia, Universidade de Brasília, 2014, p. 2.

46 Brazilian government has promoted investments in the renewable sector, especially in wind and biomass. The statistics provide that Brazil invested USD 7.6 billion in renewables between 2004 and 2013. Wind power is the renewable source of energy which attracted more investments in comparison with other renewables. REN 21. Renewables 2015 Global Status Report. 2015, p. 81-82. Available at: http://www.ren21.net/wp-content/uploads/2015/07/REN12-GSR2015 Onlinebook_low1.pdf. Access on June 28, 2016. The share of renewables in the Brazilian energy sector is much more relevant in comparision with other countries, especially the Member-States of the Organisation for Economic Co-operation and Development (OECD). PRADO, Thiago G. F. Políticas públicas e programas de desenvolvimento energético com foco em energias renováveis no brasil: do planejamento setorial de infraestrutura em energia às perspectivas de mudanças globais para o acesso e uso de recursos energéticos. 2014. $256 \mathrm{f}$. Tese (Doutorado em Engenharia Elétrica) - Faculdade de Tecnologia, Universidade de Brasília, 2014, p. 5.

47 BRASIL. Constituição Federal. Available at: http://www.planalto.gov.br/ccivil_03/ constituicao/constituicao.htm . Access on June 28, 2016.

48 Law No. 9.074/2004, article 4, paragraph 1 provides "The contracts, rights of use and amendments related to this article shall be in favor of the Federal government". ("As contratações, outorgas e prorrogações de que trata este artigo poderão ser feitas a título oneroso em favor da União"). BRASIL. Lei No 9.074, de 7 de julho de 1995. Estabelece normas para outorga e prorrogações das concessões e permissões de serviços públicos e dá outras providências. Available at: http://www.planalto.gov.br/ccivil_03/leis/L9074cons.htm. Access on June 21, 2016. 
indirectly ${ }^{49}$ explore activities of energy generation, transmission or sale of electricity, ${ }^{50}$ consolidating the reforms established in the historic panorama outlined above, which established a independence between the actors playing a role in the energy market. Such independent role shall be played separately by unrelated companies in the field of generation, transmission and distribution of energy.

The public bidding processes for energy generation and transmission are organized by the ANEEL ${ }^{51}$ observing the applicable national legislation: Law No. 10.848/2004 and Decree-Law No. $5.163 / 2004$. There are three main objectives of any bidding process established by ANEEL: pursue the best energy price, attract investors focused in the infrastructure for energy generation and retain the current energy generated. ${ }^{52}$ The duration of the concession contracts executed after the Law No. 9.074/2004 was enacted shall be no longer than thirty years with a possible renovation for the same period at the discretion of the public party. ${ }^{53}$

The first aspect of concern for a foreign investor is the openness of the country's economy to foreign capital and the legal certainty of the transactions. In case of Brazil, some sectors of its economy are still closed to corporations with foreign control, which consist of barrier of 'control criteria' to the access of foreign companies to the Brazilian market. ${ }^{54}$

In respect of the nationality of private actors in the energy sector, a reform to the Brazilian Federal Constitution was performed in 1995, eliminating the exclusivity of exploration of energy sector by the

49 Indirect exploration can be established in case of shareholder's participation in other companies.

50 Article 4, paragraph 1 provides "The contracts, rights of use and amendments related to this article shall be in favor of the Federal government". ("As contratações, outorgas e prorrogações de que trata este artigo poderão ser feitas a título oneroso em favor da União"). Law No. 9.074/2004. BRASIL. LEI No 9.074, DE 7 DE JULHO DE 1995. Estabelece normas para outorga e prorrogações das concessões e permissões de serviços públicos e dá outras providências. Available at: http://www.planalto.gov.br/ccivil_03/leis/L9074cons.htm. Access on June 21, 2016.

51 The preparation and supervision of public bidding process are one of ANEEL's responsibilities according article 3 of Law No. 9.427/1996. Public bidding documents can be accessed at ANEEL website. ANEEL. Editais de Geração. Available at: http://www.aneel.gov. $\mathrm{br} /$ geracao4. Access on June 28, 2016.

52 ANEEL. Editais de Geração. Available at: http://www.aneel.gov.br/ geracao4. Access on June 28, 2016.

53 Law No. 9.074/2004. BRASIL. Lei No 9.074, de 7 de Julho de 1995. Estabelece normas para outorga e prorrogações das concessões e permissões de serviços públicos e dá outras providências. Available at: http://www.planalto.gov.br/ccivil_03/leis/L9074cons.htm. Access on June 28, 2016.

54 DOLINGER, Jacob; TIBURCIO, Carmen. Direito Internacional Privado. Rio de Janeiro: Forense, 12a ed. Rev. atual. e ampl., 2016, p. 261. 
Brazilian corporations exclusively detained by Brazilian shareholders or Brazilian Government. ${ }^{55}$ After such amendment, companies incorporated under Brazilian laws with seat in national territory, but with foreign ownership, ${ }^{56}$ started to be authorized to hold a concession or permission agreement in the energy field.

In this scenario, it is important to make few distinctions regarding corporate nationality in accordance with Brazilian applicable legislation. ${ }^{57}$ The importance in determining the corporations' nationality relies in the definition of the status of such corporation under Brazilian law. In determining the foreign nationality, some restrictions will apply such foreign corporations that are not applicable to the Brazilian corporations..$^{58}$

According to Brazilian law, the criteria of determination of foreign nationality for corporations, in other words, the corporate's capacity and structure's recognition ${ }^{59}$ is determined by the legislation of its incorporation. ${ }^{60}$ The 'incorporation criteria' shall be used to establish the nationality of the corporation.

Differently from the 'incorporation criteria', the corporation that wishes to acquire the Brazilian nationality needs to follow another special requirement. A corporation which intends to obtain Brazilian

55 BRASIL. Emenda Constitucional no. 6 de 15 de agosto de 1995. Available at: http://www. planalto.gov.br/ccivil_03/constituicao/Emendas/Emc/emc06.htm\#art1. Access on June 28, 2016.

56 DOLINGER, Jacob; TIBURCIO, Carmen. Direito Internacional Privado. Rio de Janeiro: Forense, 12a ed. Rev. atual. e ampl., 2016, p. 186.

57 The first observation to be made in this context is related to the distinction between natural person and corporations in its conception. Jacob Dolinger explains the beginning of a life is characterized by a fact - the moment that the human being is born. The corporation starts its corporate life and acquires its nationality by means of registration of its acts of incorporation in accordance with the laws of the country of incorporation. Therefore, the corporation's beginning of a life is characterized by an act. DOLINGER, Jacob. Sociedade de Economia Mista - Subsidiária no Exterior - Autorização Legislativa. Revista de Direito Administrativo, Rio de Janeiro, v. 203, p. 346-357, p.349.

58 TIBURCIO, Carmen. Disciplina Legal da Pessoa Jurídica à Luz do Direito Internacional Brasileiro. Revista Semestral de Direito Empresarial, n. 8, 2011, p. 175-204, p.177.

59 "In this context, their capacity and structure are regulated by the law under which the company was constituted.". TIBURCIO, Carmen. Private International Law in Brazil: A brief overview. Panorama of Brazilian Law. Vol 1, No 1, 2013, p. 11-37, p. 24.

60 Article 11 of the Decree No. 4.656/1942. BRASIL. Decreto-Lei No 4.657, de 4 de setembro de 1942. Lei de Introdução às normas do Direito Brasileiro. Available at: http://www.planalto. gov.br/ccivil_03/decreto-lei/Del4657compilado.htm. Access on June 28, 2016. Jacob Dolinger highlights the definition provided in this legislation is directed to the nationality of corporations in the international scenario, establishing the criteria to define if a corporation has a foreign nationality or not. DOLINGER, Jacob. Sociedade de Economia Mista - Subsidiária no Exterior - Autorização Legislativa. Revista de Direito Administrativo, Rio de Janeiro, v. 203, p. 346-357, p. 352. 
nationality shall be incorporated in Brazil and establish its seat ${ }^{61}$ in the Brazilian territory ${ }^{62}$ as determined by the Article 60 of Decree-Law No. 2.627/1940, ${ }^{63}$ which remains valid after the Law No. 6.404/1976 was enacted.

In case of foreign corporations to exercise activities in Brazilian territory, they shall obtain special authorization of the Brazilian Government. ${ }^{64}$ After obtaining such authorization, the foreign corporation will be authorized to execute agreements, demand in Brazilian courts and be a shareholder of a Brazilian company ${ }^{65}$ (as long it maintains a special representative in the national territory with full capacity). ${ }^{66}$

Based on the foregoing, the foreign entities that would like to entry and invest in the Brazilian territory can legally exercise commercial activities through two options: obtaining Government's authorization and incorporating full branch or incorporating a subsidiary under the Brazilian laws and follow the requirements of Article 60 of Decree-Law No. 2.627/1940. In the first case, the corporation shall be submitted to the restrictions and formalities to functioning according to Brazilian legislation. In the second, the subsidiary shall observe Brazilian applicable laws, but its shares can be owned by a holding company incorporated abroad. ${ }^{67}$

Under the bidding process documents made public by ANEEL such as the auction No. 01/2016 - ANEEL for generation ${ }^{68}$, the foreign corporations were allowed to individually participate the bidding process

61 The seat shall not be the seat established in the acts of incorporation, but it shall be understood as the seat where the business activities are explored. DOLINGER, Jacob. Sociedade de Economia Mista - Subsidiária no Exterior - Autorização Legislativa. Revista de Direito Administrativo, Rio de Janeiro, v. 203, p. 346-357, p. 350.

62 DOLINGER, Jacob; TIBURCIO, Carmen. Direito Internacional Privado. Rio de Janeiro: Forense, 12 ed. Rev. atual. e ampl., 2016, p. 259.

63 BRASIL. Decreto-Lei No 2.627, de 26 de setembro de 1940. Dispõe sobre as sociedades por ações. Available at http://www.planalto.gov.br/ccivil_03/decreto-lei/Del2627.htm. Access on July $07,2016$.

64 Article 1.134 of the Brazilian Civil Code. BRASIL. Código Civil. Available at: http://www. planalto.gov.br/ccivil_03/leis/2002/110406.htm Acess on June 28, 2016.

65 Article 300 of the Law No. 6.404/76. BRASIL. Lei no 6.404, de 15 de dezembro de 1976. Dispõe sobre as Sociedades por Ações. Available at: http://www.planalto.gov.br/ccivil_03/leis/ L6404consol.htm. Access on July 07, 2016.

66 DOLINGER, Jacob; TIBURCIO, Carmen. Direito Internacional Privado. Rio de Janeiro: Forense, 12a ed. Rev. atual. e ampl., 2016, p. 265. Article 1.138 of the Brazilian Civil Code. BRASIL. Código Civil. Available at: http://www.planalto.gov.br/ccivil_03/leis/2002/110406. htm Acess on June 28, 2016.

67 TIBURCIO, Carmen. Disciplina Legal da Pessoa Jurídica à Luz do Direito Internacional Brasileiro. Revista Semestral de Direito Empresarial, n. 8, 2011, p. 175-204, p.189.

68 ANEEL. Leilão n ${ }^{\circ}$ 01/2016 - Processo nº 48500.004029/2015-41. Available at: http://www2. aneel.gov.br/aplicacoes/audiencia/arquivo/2015/079/documento/edital_leilao_a-5_2016.pdf. Access on June 28, 2016. 
as long as they create a special purpose entity (SPE) incorporated under Brazilian laws. ${ }^{69}$ The same requirement was included in the public auction No. 02/2015 - ANEEL for generation of renewable energy through wind power and biomass ${ }^{70}$, the public auction No. 06/2014 for generation of energy trough hydro, wind, solar and thermo power. ${ }^{71}$

The bidding process No. 13/2015 - ANEEL established a public auction for construction of transmission lines for electrical energy. Differently from the bidding process No. 01/2016 and No. 06/2014, in the bidding process documents No. 13/2015, foreign corporations that would compete individually were allowed to bid directly without the requirements of creating a SPE. ${ }^{72}$ In that case, the foreign corporation had to present the necessary documents to evidence its legal capacity and representatives authorized to represent the company in Brazil. In the same line were the requirements imposed by the bidding process No. 02/2016 - ANEEL for acquisition of electricity. ${ }^{73}$

Another interesting requirement is provided in case of syndication formed to participate in the public auctions for generation or transmission of electricity. In case of syndication formed by Brazilian and foreign corporations, the syndicate had mandatorily to be led by a Brazilian corporation. ${ }^{74}$ This requirement was present in all public auctions described above.

69 ANEEL. Leilão no 01/2016 - Processo no 48500.004029/2015-41. Available at: http://www2. aneel.gov.br/aplicacoes/audiencia/arquivo/2015/079/documento/edital_leilao_a-5_2016.pdf. Access on June 28, 2016, p. 6.

70 ANEEL. Leilão nº 02/2015 - Processo no 48500.005812/2014-41. Available at: http://www2. aneel.gov.br/aplicacoes/editais_geracao/documentos/EDITAL\%20LFA\%202015_.pdf. Access on June 29, 2016, p. 6.

71 ANEEL. Leilão no 06/2014 - Processo no 48500.002119/2014-16. Available at: http:// www2.aneel.gov.br/aplicacoes/editais_geracao/documentos/EDITAL_Leilao_A-5_2014_ republicacao_20len_.pdf. Access on June 29, 2016, p. 6-7.

72 ANEEL. Leilão no 13/2015 - Processo no 48500.000333/2015-19 Available at: http://www2. aneel.gov.br/aplicacoes/audiencia/arquivo/2015/080/documento/edital_leilao_13_2015 abertura_ap.pdf. Access on June 28, 2016, p. 6.

73 ANEEL. Leilão no 02/2016, Processos no 48500.003092/2014-89 e 48500.003437/201585.Available at: http://www2.aneel.gov.br/aplicacoes/editais_geracao/documentos/Edital_ leilao_02-2016_sistemas_isolados_vf.pdf Access on June 29, 2016, p. 17.

74 The consortiums formed by Brazilian private corporations and foreign corporations, the lead of the consortium shall be place to the Brazilian private corporation ("Nos consórcios formados entre pessoas jurídicas de direito privado brasileiras e estrangeiras, a liderança do consórcio caberá, sempre, à pessoa jurídica de direito privado brasileira.") ANEEL. Leilão no 13/2015 - Processo $n^{\circ}$ 48500.000333/2015-19 Available at: http://www2.aneel.gov.br/aplicacoes/ audiencia/arquivo/2015/080/documento/edital_leilao_13_2015_abertura_ap.pdf. Access on July 06, 2016, p. 7. See also: ANEEL. Leilão no 06/2014 - Processo no 48500.002119/201416. Available at: http://www2.aneel.gov.br/aplicacoes/editais_geracao/documentos/EDITAL Leilao_A-5_2014_republicacao_20len_.pdf. Access on June 29, 2016, p. 7. 


\section{A CRITICAL ANALYSIS OF THE OBSTACLES FACED BY FOREIGN INVESTORS TO ACCESS BRAZIL'S ENERGY SECTOR}

The purpose of this section is to critically analyze what elements can be considered as obstacles to the entry and maintenance of foreign investment in long-term investments specifically focused on the Brazilian's energy sector. As previously highlighted, the scope of our analysis combines FDI and energy sector. Thus, portfolio investment and other sectors in the Brazilian economy were disregarded.

There are some elements we consider as obstacles for the foreign investor's entry in the Brazilian energy market for long-term investments. The requirements imposed to the foreign corporations in the public auctions constitute, in our opinion, an example of these obstacles. Another examples of such obstacles are the legal uncertainty ${ }^{75}$, political instability, and lack of transparency, among others ${ }^{76}$. All these require more a transformation of mindset and body of law other than a single amendment of legislation. These obstacles may lay off foreign investors away from the Brazilian market, which phenomenon have a relevant impact in the government's ability to reach sources of funds to develop its infrastructure sector.

In terms of limits imposed to the foreign investment in specific sectors of the economy, there are two types of restrictions to foreigners: restrictions limiting the foreign corporations to exercise activities under strategic sectors of economy and restrictions imposed to the participation of foreign individuals in Brazilian corporations. ${ }^{77}$

The limits imposed by the national legislator to foreigners are based on the arguments of protection of national interests and protection of sectors seen as strategic and/or essential ${ }^{78}$ to the Brazilian economy. On the one hand, media and aviation are sectors that still suffer with such type of restrictions. Oil and gas and energy sectors, on the other hand, are examples of sectors that foreign participation were made

75 "Regulatory clarity and certainty are valued by businesses and citizens". OECD. Policy Framework For Investment User's Toolkit: Chapter 10. Public Governance. Available at: http:// www.oecd.org/investment/toolkit/policyareas/publicgovernance/41890394.pdf. Access on July 06, 2016, p. 2.

76 João Araujo list several policies that may hinder investments such as issues with tariff policies, characteristics of the power plants to be submitted to the public auction and political programs that do not address the needs of the energy sector. ARAUJO, João Lizardo. A Questão do Investimento no Setor Elétrico Brasileiro: Reforma e Crise. Available at: < http://www. anpec.org.br/encontro2001/artigos/200104187.pdf>. Access on July 11, 2016, p. 10-11.

77 TIBURCIO, Carmen. Disciplina Legal da Pessoa Jurídica à Luz do Direito Internacional Brasileiro. Revista Semestral de Direito Empresarial, n. 8, 2011, p. 175-204, p.184.

78 TIBURCIO, Carmen. Disciplina Legal da Pessoa Jurídica à Luz do Direito Internacional Brasileiro. Revista Semestral de Direito Empresarial, n. 8, 2011, p. 175-204, p.185. 
flexible by amendments to the Brazilian Federal Constitution occurred in the 1990's.

The Brazilian Federal Constitution provides that the ownership of any media corporation shall be restricted to Brazilian individuals or Brazilian corporations with seat in Brazil. In case of corporations, Brazilian individuals shall hold at least $70 \%$ of the total shares or of the total voting shares of the company. The owners shall mandatorily exercise the management of the activities and establish the media content. ${ }^{79}$

In aviation sector, the domestic transport is currently reserved to Brazilians corporations. ${ }^{80}$ Foreigners can only own $20 \%$ of the voting ordinary shares of such Brazilians corporations. There is an ongoing debate undergoing in the Brazilian Parliament to modify the current legislation and permit foreign shareholder control in the Brazilian corporations. ${ }^{81}$ The legislative proposal initially submitted by the Government's commission proposed an increase from $20 \%$ to $49 \%$ of the voting ordinary share authorized to be acquired by foreigners. ${ }^{82}$

In case of oil and gas sector, the previous legal regime established the Government's monopoly of the exploration of oil, gas and other hydrocarbons fluids as provided under article 177 of the original version of the Brazilian Federal Constitution. ${ }^{83}$ The constitutional monopoly suffered changes by the adoption of Constitutional Amendment n. 9 of $1995 .{ }^{84}$ "These provision were amended to maintain the Union's monopoly over oil and gas, but, at the same time, to allow International

79 Article 222 of the 1988 Brazilian Federal Constitution. BRASIL. Constituição da República Federativa do Brasil DE 1988. http://www.planalto.gov.br/ccivil_03/Constituicao/Constituicao. htm. Access on July 08, 2016.

80 (“Art. 216. Os serviços aéreos de transporte público doméstico são reservados às pessoas jurídicas brasileiras.”) BRASIL. Lei No 7.565, de 19 de dezembro de 1986. Dispõe sobre o Código Brasileiro de Aeronáutica. Available at: http://www.planalto.gov.br/ccivil_03/leis/ L7565.htm Access on July 08, 2016.

81 The aviation sector is one example of the restriction of foreign capital in the corporations exploring activities in sensitive sector of Brazilian economy. Recently, the parliament approved the participation of $100 \%$ of foreign capital in the ordinary shares of Brazilian corporations. CAMARA DOS DEPUTADOS. http://www2.camara.leg.br/camaranoticias/noticias/ TRANSPORTE-E-TRANSITO/511051-CAMARA-APROVA-MP-QUE-PERMITE-100-DECAPITAL-ESTRANGEIRO-EM-EMPRESAS-AEREAS.html. Access on June 28, 2016.

82 BRASIL. Medida provisória $n^{\circ} 714$, de $1^{\circ}$ de março de 2016. Extingue o Adicional de Tarifa Aeroportuária e altera a Lei $\mathrm{n}^{\circ}$ 5.862, de 12 de dezembro de 1972, e a Lei $\mathrm{n}^{\mathrm{0}} 7.565$, de 19 de dezembro de 1986. http://www.planalto.gov.br/ccivil_03/_Ato2015-2018/2016/Mpv/mpv714. htm\#art4. Access on July 07, 2016.

83 BRASIL. Constituição da República Federativa do Brasil DE 1988. http://www.planalto. gov.br/ccivil_03/Constituicao/Constituicao.htm. Access on July 08, 2016.

84 BRASIL. Emenda Constitucional no. 9 de 09 de novembro de 1995. Available at: http://www. planalto.gov.br/ccivil_03/constituicao/emendas/emc/emc09.htm. Access on July 08, 2016. 
Oil Companies to act in Brazil". ${ }^{85}$ The Constitutional Amendment $\mathrm{n}$. 9 had a significant impact and reoriented the Brazilian legal system regarding exploration of oil and gas. ${ }^{86}$

In case of energy sector, the Constitutional Amendment n. 6 of 1995 amended the first paragraph of article 176 of the Brazilian Federal Constitution excluding the concept of Brazilian corporation with "national shares". ${ }^{87}$ After such amendment, Brazilian corporations with foreign ownership were allowed to explore hydro-generation energy, eliminating the requirement of the shares to be owned by Brazilian individuals.

Another type of restriction to the access of foreigners to the Brazilian market is connected with the formalities imposed to the foreigners under public auctions for concession agreements. It is understood the administrative burden of a legal system may reduce the interest of investors in a certain country. The excess of requirements to pursue administrative simple procedures and its time-length may result in an excessive cost negatively effect on the investor's decision to invest.

In the Brazilian energy markets, it is common to find requirements related to syndications formed by Brazilian and Foreign corporations in the public auction process for energy concessions. In the public bidding documents analyzed above, in case of syndication with participation of a foreign corporation, a Brazilian corporation shall lead the syndication, not the foreign corporation. Not allowing a foreign corporation to lead a syndicate is an example of the barriers imposed under concessions in infrastructure projects that we currently face in Brazil. The result of the imposition of this type of barrier is the difficulty to attract foreign investment. ${ }^{88}$

Another example of excess of administrative burden imposed to foreign corporations is the requirement of creation of a special purpose entity. In the public bidding documents analyzed above, the foreign corporations that win the bid shall create a special purpose entity to execute the concession agreement.

A third example can be represented by the preference given to the Brazilian bidders participating of any type of public bidding process occurred in Brazil. Brazilian corporations' bid have preference

85 ALMADA, Laís P.; PARENTE, Virgínia. Oil \& Gas Industry in Brazil: A brief history and legal framework. Panorama of Brazilian Law. Vol 1, No 1, 2013, p. 223-252, p. 227.

86 RIBEIRO, Marilda. Direito do Petróleo. Rio de Janeiro: Renovar, 3a ed. rev., atual. e ampl, 2014, p. 407.

87 BRASIL. Emenda Constitucional no. 6 de 15 de agosto de 1995. Available at: http://www. planalto.gov.br/ccivil_03/constituicao/Emendas/Emc/emc06.htm\#art1. Access on June 28, 2016.

88 BAPTISTA, Patricia. Governança Pública e Aperfeiçoamento Institucional da Administração Pública: Características fundamentais e perspectivas para a atuação do poder público de forma a atrair investimentos estrangeiros. In: Simpósio Estadual de Investimentos. Rio de Janeiro: Procuradoria do Estado do Rio de Janeiro, I, 2016. 
in comparison with the bid of foreign corporations ${ }^{89}$. According to article 3, paragraph 2 of the Law No. 8666/93 the tie-bracking criteria to decide between bids with equal conditions given in a public auction shall be the criteria of products and services provided by Brazilian corporations. ${ }^{90}$ This provision can also be considered a hindrance to foreign investment's entry.

In the opinion of Patricia Baptista, the model of public bidding process and applicable legislation does not attract the type of investment the Brazilian Government should wish. The reason for that is because the concession contracts with Brazilian States is so favorable to the State itself and the Brazilian Judiciary is so paternalist and protective the result is a non-profit relationship for the foreign investor. An example of such paternalism is the non-observation of the right of the private party of the concession agreement to terminate it at the time the public party delays the payment fore a period equal to or more than 90 days as provided in the Article 78, XV of the Law No. 8.666/93. ${ }^{91}$

Nevertheless the attractiveness of the Brazilian energy sector in terms, of natural resources ${ }^{92}$, extensive territory, the challenges faced by foreign investors do not encourage the attraction of private funds. Some still argue one of the main issues of foreign investor's at the entrance in the Brazilian market is the concern with legal uncertainty ${ }^{93}$ Some aspects of such uncertainty are reflected in the regulatory panorama, lack of national standards to guarantee the safety to foreign investors and culture of trust of the private sector in the public regulatory entities.

The Organization for Economic Co-operation and Development (OECD) developed a guide on public governance that highlights six elements inherent to the good governance: "accountability, transparency, efficiency, effectiveness, responsiveness and rule of law"94. These

89 TIBURCIO, Carmen. Disciplina Legal da Pessoa Jurídica à Luz do Direito Internacional Brasileiro. Revista Semestral de Direito Empresarial, n. 8, 2011, p. 175-204, p.177.

90 BRASIL. Lei no 8.666 de 21 de junho de 1993. Regulamenta o art. 37, inciso XXI, da Constituição Federal, institui normas para licitações e contratos da Administração Pública e dá outras providências. Available at: http://www.planalto.gov.br/ccivil_03/decreto-lei/De18031. htm. Access on July 06, 2016.

91 BRASIL. Lei $\mathrm{n}^{\circ} 8.666$ de 21 de junho de 1993. Regulamenta o art. 37, inciso XXI, da Constituição Federal, institui normas para licitações e contratos da Administração Pública e dá outras providências. Available at: http://www.planalto.gov.br/ccivil_03/decreto-lei/Del8031. htm. Access on July 06, 2016.

92 Brazilian territory permits a range of source of energy and space to implement different plants such wind, hydro and solar power plants.

93 BAPTISTA, Patricia. Governança Pública e Aperfeiçoamento Institucional da Administração Pública: Características fundamentais e perspectivas para a atuação do poder público de forma a atrair investimentos estrangeiros. In: Simpósio Estadual de Investimentos. Rio de Janeiro: Procuradoria do Estado do Rio de Janeiro, I, 2016.

94 OECD. Policy Framework For Investment User's Toolkit: Chapter 10. Public Governance. 
elements are necessary to maximize the investment flow in the countries based on the trust and certainty as base-ground assumptions observed by the investors at the first step of an investment's decision.

In respect to those elements, the corruption is an issue that remains present in different scenarios of the relationship between public and private sector, which has generated a scenario of political instability. Brazil is currently appointed as very corrupt under the '2015 Corruption Perceptions Index' holding the position 78 of 168's world countries ranking. ${ }^{95}$ In addition, the latest events involving corruption's investigations in the public sector and oil and gas industry had a strong impact in the economic scenario. ${ }^{96}$

Transparency can also be considered an issue in several layers: transparent rules, making the obligations of foreign investors clear and predictable. Transparent administrative procedures, clarifying to the private sector the cost efficiency of the investment to be made, are practices that need to be present in a developed market. In both cases, Brazil does not present the elements of public governance as established by OECD. ${ }^{97}$

All the elements to build good governance should be observed by Brazilian's Government to improve its capacity of attraction of foreign source of funds. Public governance "helps build trust and provides rules and stability needed for planning investment in the medium and long term" ${ }^{98}$ The consequences for a non-attractive environment for foreign investors are the lack of interest in the Brazilian concession bids and scarcity of financial sources to develop the electricity industry.

In our recent past, we have observed some cases of public

Available at: http://www.oecd.org/investment/toolkit/policyareas/publicgovernance/41890394. pdf. Access on July 06, 2016, p. 2.

95 Denmark is positioned as the first of the world's ranking, being the country most clean in terms of corruption. TRANSPARENCY INTERNATIONAL. Available at: https://www. transparency.org/cpi2015/. Access on July 06, 2016.

96 An example of the consequences of the political instability and consequences of the corruptions events and investigatios occurred in Brazil: the country's rating was downgraded by the International Rating Agencies. MOODY'S INVESTORS SERVICE. Moody's rebaixa rating do Brasil para Baa3 de Baa2; perspectiva é alterada para estável, 11 ago. 2015. Available at: <https://www.moodys.com/research/ Moodys-rebaixa-rating-do-Brasil-para-Baa3-deBaa2-perspectiva-PR_332264?lang=pt\&cy=bra $>$. Access on July 11, 2016.

97 In terms of concession in the energy sector, an example of the lack of transparency occurred in the Light concession. According to João Araújo, the concession agreement presented favorable clauses to the contracting party, but these clauses were proven not as favorable as Light imagined. ARAUJO, João Lizardo. A Questão do Investimento no Setor Elétrico Brasileiro: Reforma e Crise. Available at: < http://www.anpec.org.br/encontro2001/artigos/200104187. pdf $>$. Access on July 11, 2016, p. 10.

98 OECD. Policy Framework For Investment User's Toolkit: Chapter 10. Public Governance. Available at: http://www.oecd.org/investment/toolkit/policyareas/publicgovernance/41890394. pdf. Access on July 06, 2016, p. 2. 
auction's abandonment by the private sector. Even international companies with high expertize in some sectors of the economy, such as the energy sector, abandoned public auctions in Brazil due to the lack of interest in the terms of conditions of the bidding process.

An example of this situation was the public bidding process to contract with an energy generation provider in 2015 necessary for the Olympics in Rio. ${ }^{99}$ Four years before, the multinational corporation 'Aggreko', one of the experts company in such type of electricity provider service, has predicted a relevant opportunity of investment for the sport events in Brazil, such as the World Cup and Olympics. Looking for such type of opportunities, the multinational Aggreko opened 12 offices in Brazil. ${ }^{100}$ However, after having participated in the World Cup concession agreement, Aggreko decided not to participate in the public bidding of 2015 to provide energy in the Olympics in Rio de Janeiro. Despite the concern of Municipal government of Rio de Janeiro with finding remedies for such deserted public auction, there is no debate in the media or any other forum regarding the reasons for such abandonment by Aggreko.

This type of abandonment of public auctions is a concern for the economy of a country. It is impressive not seen any type of manifestation from the public authorities in terms of motivation to change the current scenario private investors face.

In conclusion, public authorities in Brazil should be more interested in addressing the needs of the private sector, especially the foreign investors, to improve a more benefic environment for investment. Provisions fulfilled with consistency and coherence for the entrance of foreign investment in the national territory and certainty for long-term investments are vital for the development of the infrastructure. Public governance shall focus on a dynamic, efficient, long-term agenda for investment attraction and infrastructure development.

It is necessary to highlight that aiming for efficiency and effectiveness in the regulatory framework and prioritize good governance is not synonym of deregulation. "Regulations which encourage market dynamism, innovation and competitiveness improve economic performance". 101

99 REUTERS. Geradora de energia Aggreko se retira de licitação para Jogos Rio 2016. Available at: http://br.reuters.com/article/sportsNews/idBRKBN0TX1WU20151214. Access on July $08,2016$.

100 ISEBVMF. Infraestrutura - Fornecedores de serviços reforçam bases no país. http://isebvmf. com.br/?r=noticias/view\&id=226910. Access on July 08, 2016.

101 OECD. Policy Framework For Investment User's Toolkit: Chapter 10. Public Governance. Available at: http://www.oecd.org/investment/toolkit/policyareas/publicgovernance/41890394. pdf. Access on July 06, 2016, p. 4. 


\section{Conclusion}

The relevance of the energy sector to a country's economy requires a significant amount of investment necessary for the infrastructure involving the generation, transmission and distribution of electricity to its population. Concerned with the volume of investment required for development, public authorities shall focus on the mechanisms of attraction of the investors.

Departing from that assumption, the historic outlook presented in the first section recapitulated several events that modified the legislative and regulatory panorama of the energy sector. The creation of the Code of Waters, the Concessions Law, Energy Concession Law and segmentation of the energy sectors in generation, transmission and distribution were events looking for improvement of the energy market. These events had one main objective: create competition with less State-intervention and more participation of the private sector as source of investment.

Notwithstanding all changes made to the legislative panorama over the energy sector, requirements imposed to foreign investors remained in the public auction documents. After an analysis of bidding process provisions established by ANEEL, a number of requirements inflicted to foreign corporations were identified. These requirements play more a role of hindrance of investments than to protect national market.

Along with issues such as legal uncertainty, political instability, administrative burden and lack of transparency present in the Brazilian system as a whole, these requirements negatively impact the energy sector instead of improving it. After a critical analysis of the obstacles faced by foreign investors to access Brazil's energy sector, the conclusion is a necessary reformulation of the regulatory framework to eliminate such type of hindrances to the access of foreign investor's access to the infrastructure sector. "Regulations which are poorly designed or weakly applied can slow business responsiveness, divert resources away from productive investments, hamper entry into markets, reduce job creation and generally discourage entrepreneurship." 102

Public authorities shall value for a regulatory framework that promotes efficiency and effectiveness. Good governance with all its inherent elements shall drive public policies, building a system with stability and incentives necessary to plan investments in the medium and long term by private investors. Brazil needs to eliminate the issues found in the concession bidding process, the administrative burden and promote the participation of the private sector to pursue infrastructure

102 OECD. Policy Framework For Investment User's Toolkit: Chapter 10. Public Governance. Available at: http://www.oecd.org/investment/toolkit/policyareas/publicgovernance/41890394. pdf. Access on July 06, 2016, p. 4. 
projects, developing the economy, improving wide access and competition in the energy sector. The risk of not adoption measures like this is the danger of facing a new energetic crisis and suffer with difficulties related to scarcity of source of funds.

\section{REFERENCES}

ALMADA, Laís P.; PARENTE, Virgínia. Oil \& Gas Industry in Brazil: A brief history and legal framework. Panorama of Brazilian Law. Vol 1, No 1, 2013, p. 223-252.

ANEEL. Editais de Geração. Available at: http://www.aneel.gov.br/ geracao4. Access on June 28, 2016.

ANEEL. Leilão $n^{\circ}$ 06/2014 - Processo $n^{\circ}$ 48500.002119/2014-16. Available at: http://www2.aneel.gov.br/aplicacoes/editais_geracao/ documentos/EDITAL_Leilao_A-5_2014_republicacao_20len_.pdf. Access on June 29, 2016, p. 6-7.

. Leilão n ${ }^{\circ}$ 02/2015 - Processo n ${ }^{\circ} 48500.005812 / 2014-41$. Available at: http://www2.aneel.gov.br/aplicacoes/editais_geracao/documentos/ EDITAL\%20LFA\%202015_.pdf. Access on June 29, 2016.

. Leilão n ${ }^{\circ} 13 / 2015$ - Processo no 48500.000333/2015-19 Available at: http://www2.aneel.gov.br/aplicacoes/audiencia/arquivo/2015/080/ documento/edital_leilao_13_2015_abertura_ap.pdf. Access on June 28, 2016.

Leilão $n^{0} \quad 01 / 2016$ - Processo $n^{0} 48500.004029 / 2015-$ 41. Available at: http://www2.aneel.gov.br/aplicacoes/audiencia/ arquivo/2015/079/documento/edital_leilao_a-5_2016.pdf. Access on June 28, 2016.

. Leilão $n^{\circ}$ 02/2016, Processos $n^{0} 48500.003092 / 2014-89$ e 48500.003437/2015-85.Available at: http://www2.aneel.gov.br/ aplicacoes/editais_geracao/documentos/Edital_leilao_02-2016_ sistemas_isolados_vf.pdf Access on June 29, 2016.

ARAUJO, João Lizardo. A Questão do Investimento no Setor Elétrico Brasileiro: Reforma e Crise. Available at: < http://www.anpec.org.br/ encontro2001/artigos/200104187.pdf>. Access on July 11, 2016.

BAPTISTA, Patricia. Governança Pública e Aperfeiçoamento Institucional da Administração Pública: Características fundamentais e perspectivas para a atuação do poder público de forma a atrair investimentos estrangeiros. In: Simpósio Estadual de Investimentos. Rio de Janeiro: Procuradoria do Estado do Rio de Janeiro, I, 2016.

BNDES. Available at: http://www.bndes.gov.br/SiteBNDES/export/ 
sites/default/bndes_pt/Galerias/Arquivos/conhecimento/pnd/Priv_Gov. PDF. Access on June 24, 2016.

BRASIL. Câmara dos Deputados. Decreto n ${ }^{\circ}$ 24.643/1934 de 10 de julho 1934. Available at: http://www2.camara.leg.br/legin/ fed/decret/1930-1939/decreto-24643-10-julho-1934-498122publicacaooriginal-1-pe.html. Access on June 21, 2016.

. Código Civil. Available at: http://www.planalto.gov.br/ ccivil_03/leis/2002/110406.htm Acess on June 28, 2016.

. Constituição da República Federativa dos Estados Unidos do Brasil de 16 de Julho de 1934. Available at: http://www.planalto.gov. br/ccivil_03/Constituicao/Constituicao34.htm Access on June 24, 2016.

. Constituição da República Federativa do Brasil DE 1988. http:// www.planalto.gov.br/ccivil_03/Constituicao/Constituicao.htm. Access on July 08, 2016.

. Decreto-Lei $N^{\circ} 852$, de 11 de novembro de 1938. Mantém, com modificações, o decreto n. 24.643, de 10 de julho de 1934 e dá outras providências. Available at: http://www.planalto.gov.br/ccivil_03/ decreto-lei/1937-1946/Del0852.htm . Access on June 21, 2016.

Decreto-Lei $N^{o}$ 2.627, de 26 de setembro de 1940. Dispõe sobre as sociedades por ações. Available at http://www.planalto.gov.br/ ccivil_03/decreto-lei/Del2627.htm. Access on July 07, 2016.

- Decreto-Lei $\mathrm{n}^{\mathrm{o}} 3.763 / 1941$ Consolida disposições sobre águas e energia elétrica, e dá outras providências. Available at: http:// www.planalto.gov.br/ccivil_03/Decreto-Lei/1937-1946/De13763. htm\#art144c. Access on June $\overline{2} 3,2016$.

. Decreto-Lei $N^{0} 4.657$, de 4 de setembro de 1942. Lei de Introdução às normas do Direito Brasileiro. Available at:

- Decreto 5.163/2004. Regulamenta a comercialização de energia elétrica, o processo de outorga de concessões e de autorizações de geração de energia elétrica, e dá outras providências. Available at: http://www.planalto.gov.br/ccivil_03/_ato2004-2006/2004/decreto/ d5163.HTM. Access on June 28, $20 \overline{16}$.

. Decreto-Lei $n^{\circ} 8.031$ de 03 de outubro de 1945. Autoriza a organização da Companhia Hidro Elétrica do São Francisco. Available at: http://www.planalto.gov.br/ccivil_03/decreto-lei/Del8031.htm. Access on June 23, 2016.

. Emenda Constitucional no. 6 de 15 de agosto de 1995. Available at: http://www.planalto.gov.br/ccivil_03/constituicao/Emendas/Emc/ emc06.htm\#art1. Access on June 28, $2 \overline{0} 16$. 
. Emenda Constitucional no. 9 de 09 de novembro de 1995. Available at: http://www.planalto.gov.br/ccivil_03/constituicao/ emendas/emc/emc09.htm. Access on July 08, 2016.

Lei $N^{0}$ 3.890-A, de 25 de abril de 1961. Autoriza a União a constituir a empresa Centrais Elétricas Brasileiras S.A. - ELETROBRÁS, e dá outras providências. Available at: http://www.planalto.gov.br/ ccivil_03/leis/L3890Acons.htm Access on June 24, 2016.

. Lei no 6.404 , de 15 de dezembro de 1976. Dispõe sobre as Sociedades por Ações. Available at: http://www.planalto.gov.br/ ccivil_03/leis/L6404consol.htm. Access on July 07, 2016.

. Lei $\mathrm{N}^{\mathrm{0}} 7.565$, de 19 de dezembro de 1986. Dispõe sobre o Código Brasileiro de Aeronáutica. Available at: http://www.planalto. gov.br/ccivil_03/leis/L7565.htm Access on July 08, 2016.

. Lei $N^{0} 8.422 / 1992$. Dispõe sobre a organização de ministérios e dá outras providências. Available at: http://www.planalto.gov.br/ ccivil_03/leis/L8422.htm. Access on June 24, 2016.

. Lei $\mathrm{n}^{\circ} 8.666$ de 21 de junho de 1993. Regulamenta o art. 37, inciso XXI, da Constituição Federal, institui normas para licitações e contratos da Administração Pública e dá outras providências. Available at: http://www.planalto.gov.br/ccivil_03/decreto-lei/Del8031.htm. Access on July 06, 2016.

. Lei No 8.987, de 13 de fevereiro de 1995. Dispõe sobre o regime de concessão e permissão da prestação de serviços públicos previsto no art. 175 da Constituição Federal, e dá outras providência. Available at: http://www.planalto.gov.br/ccivil_03/leis/L8987cons.htm Access on June 21, 2016.

. Lei $\mathrm{N}^{0}$ 9.074, de 7 de julho de 1995. Estabelece normas para outorga e prorrogações das concessões e permissões de serviços públicos e dá outras providências. Available at: http://www.planalto. gov.br/ccivil_03/leis/L9074cons.htm Access on June 21, 2016.

. Lei $\mathrm{N}^{0} 10.848$ de 15 de março de 2004. Dispõe sobre a comercialização de energia elétrica. Available at: http://www.planalto. gov.br/ccivil_03/_ato2004-2006/2004/lei/110.848.htm. Access on June 23, 2016.

as concessões de geração, transmissão e distribuição de energia elétrica, sobre a redução dos encargos setoriais e sobre a modicidade tarifária. Available at: http://www.planalto.gov.br/ccivil_03/_ato20112014/2013/Lei/L12783.htm Access on July 06, 2016.

. Medida provisória $n^{\circ} 714$, de $1^{\circ}$ de março de 2016. Extingue 
o Adicional de Tarifa Aeroportuária e altera a Lei $\mathrm{n}^{0} 5.862$, de 12 de dezembro de 1972, e a Lei $\mathrm{n}^{\circ} 7.565$, de 19 de dezembro de 1986. http:// www.planalto.gov.br/ccivil_03/_Ato2015-2018/2016/Mpv/mpv714. htm\#art4. Access on July 07, $201 \overline{6}$.

. Ministério de Minas e Energia. Available at: http://www. mme.gov.br/web/guest/pagina-inicial/manchete/-/asset_publisher/ neRB8QmDsbU0/content/setor-eletrico-brasileiro-esta-aberto-ainvestimentos-estrangeiros-e-sem-restricoes-diz-braga;jsessionid=148 F3A851FC66A0C0AEAA8D601BE0195.srv154. Access on June 28, 2016.

CAMARA DOS DEPUTADOS. http://www2.camara.leg.br/ camaranoticias/noticias/TRANSPORTE-E-TRANSITO/511051CAMARA-APROVA-MP-QUE-PERMITE-100-DE-CAPITALESTRANGEIRO-EM-EMPRESAS-AEREAS.html. Access on June 28, 2016.

CCEE. Available at: https://www.ccee.org.br. Access on June 24, 2016. CALDAS, Geraldo Pereira. Concessões de serviços públicos de energia elétrica. 2a ed., Curitiba. Juruá, 2011

COSTA, José Augusto Fontoura. Direito internacional do investimento estrangeiro. Curitiba: Juruá, 2010.

DOLINGER, Jacob; TIBURCIO, Carmen. Direito Internacional Privado. Rio de Janeiro: Forense, 12 ed. Rev. atual. e ampl., 2016.

DOLINGER, Jacob. Sociedade de Economia Mista - Subsidiária no Exterior - Autorização Legislativa. Revista de Direito Administrativo, Rio de Janeiro, v. 203, p. 346-357.

DOLZER, Rudolph; SCHREUER, Christoph. Principles of International Investment Law. Oxford: Oxford University Press, 2. ed., 2012.

GALLO, Fabiano; LOBIANCO, Eduardo L. Electricity regulation in Brazil: overview. Available at: http://us.practicallaw.com/8-5457207?q=campos + mello. Access on June 30, 2016.

GANIM, Antonio. Setor elétrico brasileiro: aspectos regulamentares, tributários e contábeis. Brasília: Canal Energia: Synergia, 2009.

KAERCHER Loureiro, Luiz Gustavo. A Indústria Elétrica e o Código de Águas. Porto Alegre: Fabris, 2007.

LEAL-ARCAS, Rafael; FILIES, Andrew; ABU GOSH, Ehab S. International Energy Governance: Selected Legal Issues. Cheltenham: Edward Elegar, 2014.

MOODY'S INVESTORS SERVICE. Moody's rebaixa rating do Brasil para Baa3 de Baa2; perspectiva é alterada para estável, 11 
ago. 2015. Available at: <https://www.moodys.com/research/ Moodys-rebaixa-rating-do-Brasil-para-Baa3-de-Baa2-perspectivaPR_332264?lang=pt\&cy=bra>. Access on July 11, 2016.

OECD. Policy Framework For Investment User's Toolkit: Chapter 10. Public Governance. Available at: http://www.oecd.org/investment/ toolkit/policyareas/publicgovernance/41890394.pdf. Access on July 06, 2016.

PRADO, Thiago G. F. Políticas públicas e programas de desenvolvimento energético com foco em energias renováveis no brasil: do planejamento setorial de infraestrutura em energia às perspectivas de mudanças globais para o acesso e uso de recursos energéticos. 2014. $256 \mathrm{f}$. Tese (Doutorado em Engenharia Elétrica) - Faculdade de Tecnologia, Universidade de Brasília, 2014.

REUTERS. Geradora de energia Aggreko se retira de licitação para Jogos Rio 2016. Available at: http://br.reuters.com/article/sportsNews/ idBRKBN0TX1 WU20151214. Access on July 08, 2016.

RIBEIRO, Marilda. Direito do Petróleo. Rio de Janeiro: Renovar, 3 a ed. rev., atual. e ampl, 2014.

ROLIM, MARIA J. Direito Econômico da Energia Elétrica. Rio de Janeiro: Forense, 1a ed., 2002.

SORNARAJAH, M. The International Law on Foreign Investment. 3rd ed., New York: Cambridge University Press, 2010.

TIBURCIO, Carmen. Private International Law in Brazil: A brief overview. Panorama of Brazilian Law. Vol 1, No 1, 2013, p. 11-37.

TIBURCIO, Carmen. Disciplina Legal da Pessoa Jurídica à Luz do Direito Internacional Brasileiro. Revista Semestral de Direito Empresarial, n. 8, 2011, p. 175-204.

TOLMASQUIM. Maurício T. Novo Modelo do Setor Elétrico Brasileiro. Rio de Janeiro: Synergia, 2a ed., 2011.

TRANSPARENCY INTERNATIONAL. Available at: https://www. transparency.org/cpi2015/. Access on July 06, 2016. 